\title{
Defining clinical remission and clinically inactive disease in juvenile systemic lupus erythematosus (jSLE)
}

\author{
Rina Mina ${ }^{1 *}$, Laura Schanberg ${ }^{2}$, Anne B Eberhard ${ }^{3}$, Marisa Klein-Gitelman ${ }^{4}$, Gloria Higgins $^{5}$, Karen Onel ${ }^{6}$, \\ Nora G Singer ${ }^{7}$, Kathleen $\mathrm{O}^{\prime}$ Neil $^{8}$, Lori Tucker $^{9}$, Deborah Levy ${ }^{10}$, Wajeeha Yousaf ${ }^{11}$, Shannen Nelson', \\ Michael Beresford ${ }^{12}$, Ruben Cuttica ${ }^{13}$, Graciela Espada ${ }^{14}$, Angelo Ravelli ${ }^{15}$, Alberto Martini ${ }^{15}$, Edward Giannini $^{1}$, \\ Hermine I Brunner ${ }^{1}$ \\ From 18th Pediatric Rheumatology European Society (PReS) Congress \\ Bruges, Belgium. 14-18 September 2011
}

\section{Background}

An initial Delphi survey delineated key commonalities for a standard definition of clinical remission and inactive disease in jSLE. However, several additional clarifications were still required.

\section{Objective}

To develop a definition and criteria of clinical remission and inactive disease in jSLE.

\section{Methods}

A second international Delphi survey was conducted among pediatric rheumatologists. Consensus was set at $75 \%$.

\section{Results}

There were 210 respondents. Consensus was achieved regarding the key definitions under consideration (Table 1). Respondents also agreed that a) there should be at most one mild, non-limiting symptom; and b) there can be regular use of several systemic medications in clinical remission. There was no consensus on whether select laboratory tests could be abnormal, and whether regular use of non-steroidal anti-inflammatory drugs with clinical remission was permissible.

\section{Conclusions}

Consensus has been reached on the definition of 'Clinical Remission' and 'Clinically Inactive Disease' in jSLE.

Table 1 Definition of Clinical Remission and Clinically Inactive Disease in JSLE

\begin{tabular}{|c|c|c|c|c|c|c|}
\hline \multirow[t]{2}{*}{ Construct } & \multirow[t]{2}{*}{ Time frame } & \multicolumn{4}{|c|}{ Acceptable Use of Medications for Lupus } & \multirow[t]{2}{*}{ Consensu } \\
\hline & & $\begin{array}{l}\text { Cortico } \\
\text { steroids }\end{array}$ & $\begin{array}{l}\text { Immuno } \\
\text { suppressives }\end{array}$ & $\begin{array}{l}\text { Preventive } \\
\text { medications }\end{array}$ & $\begin{array}{l}\text { Medications to treat } \\
\text { SLE damage }\end{array}$ & \\
\hline Clinically Inactive Disease & Time-point & Yes & Yes & Yes & Yes & $\begin{array}{l}94 \%(156 / \\
166)\end{array}$ \\
\hline $\begin{array}{l}\text { Clinical Remission on } \\
\text { Medication }\end{array}$ & $\begin{array}{l}\text { Time-period: } \geq 6 \\
\text { months }\end{array}$ & Yes & Yes & Yes & Yes & $\begin{array}{l}96 \%(159 / \\
166)\end{array}$ \\
\hline $\begin{array}{l}\text { Clinical Remission on } \\
\text { Preventive Medication }\end{array}$ & $\begin{array}{l}\text { Time-period: } \geq 6 \\
\text { montHs }\end{array}$ & No & No & Yes & Yes & $\begin{array}{l}95 \%(154 / \\
162)\end{array}$ \\
\hline $\begin{array}{l}\text { Clinical Remission Off } \\
\text { Medication }\end{array}$ & $\begin{array}{l}\text { Time-period: } \geq 12 \\
\text { months }\end{array}$ & No & No & No & Yes & $\begin{array}{l}86 \%(140 / \\
162)\end{array}$ \\
\hline
\end{tabular}

* Correspondence: rina.mina@cchmc.org

'Cincinnati Children's Med Ctr, USA

Full list of author information is available at the end of the article 
The results of the Delphi process will be used to guide the data-driven development of provisional criteria of clinical remission and inactive disease in jSLE.

\section{Author details}

${ }^{1}$ Cincinnati Children's Med Ctr, USA. ${ }^{2}$ Duke Children's Hosp, USA. ${ }^{3}$ Cohen Children's Medical Ctr, USA. ${ }^{4}$ Children's Memorial Hosp, USA. ${ }^{5}$ Nationwide Children's Hosp, USA. 'University of Chicago Comer Children's Hosp, USA. ${ }^{7}$ MetroHealth Medical Center, OH, USA. ${ }^{8}$ Children's Hosp at Oklahoma University, USA. ${ }^{9}$ BC Children's Hosp, Canada. ${ }^{10}$ The Hospital for Sick Children, Canada. ${ }^{11}$ University of Cincinnati, OH, USA. ${ }^{12}$ Royal Liverpool Children's NHS Trust, UK. ${ }^{13}$ Hospital General de Niños Pedro de Elizalde Argentina. ${ }^{14}$ Hospital de Niños Dr. Ricardo Gutiérrez, Buenos Aires, Argentina. ${ }^{15}$ University of Genova, Istituto G. Gaslini, Italy.

Published: 14 September 2011

doi:10.1186/1546-0096-9-S1-017

Cite this article as: Mina et al:: Defining clinical remission and clinically inactive disease in juvenile systemic lupus erythematosus (jSLE).

Pediatric Rheumatology 2011 9(Suppl 1):017.

\section{Submit your next manuscript to BioMed Central} and take full advantage of:

- Convenient online submission

- Thorough peer review

- No space constraints or color figure charges

- Immediate publication on acceptance

- Inclusion in PubMed, CAS, Scopus and Google Scholar

- Research which is freely available for redistribution

Submit your manuscript at www.biomedcentral.com/submit 